ÁREA ABIERTA No 29. JULIO 2011

Referencia: AA29.1107.148

"Presencia del teatro en los medios de comunicación españoles como forma de promoción"

AUTOR: Dr. CALDEVILLA DOMíNGUEZ, David . Universidad Complutense de Madrid.

\title{
PRESENCIA DEL TEATRO \\ EN LOS MEDIOS DE \\ COMUNICACIÓN ESPAÑOLES \\ COMO FORMA DE PROMOCIÓN
}

Presence of the theatre in the Spanish media as a means of promoting 


\title{
RESUMEN
}

El teatro conserva un público estable en una época de continuos avances tecnológicos en el ocio audiovisual. El presente artículo aborda la presencia de las distintas manifestaciones del teatro en los medios de comunicación (radio, prensa y televisión), ya que ellos son los principales divulgadores del mundo de las artes escénicas entre el gran público. En nuestra investigación de campo se pone de manifiesto que, pese a no disfrutar de una mayoritaria afluencia a las salas, el teatro conserva un prestigio que ha llevado a algunos expertos a hablar de "liderazgo cultural". No obstante, es un hecho que ha pasado a un plano secundario de interés en la programación diaria de los medios de comunicación generalistas, lo que podría sugerir una menor relevancia en la Opinión Pública. Las encuestas muestran, paradójicamente, lo contrario: el teatro ve aumentado su número de espectadores (pese a la dura crisis económica), aunque siga tratándose de un público menos numeroso que el que consume televisión o cine. En esta investigación, realizada con datos recogidos entre los años 1999 y 2009, analizaremos el impacto real de la Opinión Pública en los medios de comunicación españoles.

Palabras clave: teatro, promoción teatral, medios de comunicación, artes escénicas, Opinión Pública.

\begin{abstract}
The theatre maintains a stable public in an age of continuous technological advances in audiovisual entertainment. This article discusses the presence of the different forms of theatre in the media (radio, press and television), because they are the main disseminators of the world of performing arts among the general public. Our research shows that, despite not enjoying a majority influx into the auditoriums, the theatre retains a prestige that has led some experts to talk about "cultural leadership". However, it is a fact that has become a secondary role in the daily schedule of the general media, which might suggest a lesser importance in Public Opinion. Surveys show the opposite: the number of viewers rises, while still dealing with a public less numerous than the audience for television and film, despite the actual economic crisis. In this research, conducted with data collected between 1999 and 2009, we analyze the real impact of Public Opinion in the Spanish media.
\end{abstract}

Key Words: theatre, theatrical promotion, media, performing arts, public opinion. 


\section{Introducción}

El presente trabajo es fruto de una investigación de campo sobre el disfrute del tiempo de ocio por parte de los españoles en el período 199-2009. No responde a una hipótesis previa ya que se desarrolló la investigación bajo el método inductivo, no hipotético-deductivo, ya que se deseaba conocer el estado de la cuestión a través, y esto sí supone una hipótesis, de su exacto reflejo en los Medios de Comunicación para Masas. A partir de la presencia del teatro en los Medios, se podrán establecer estrategias de mejora en su imagen, al aplicar fórmulas de Relaciones Públicas, para que la Cultura española pueda volver a asentar uno de sus pilares cumeros como lo es el arte escénica.

Los esfuerzos del teatro por renovarse y mantener su popularidad han sido muchos y notables desde hace años: Ofertas, rotación amplia de títulos, intervención de rostros conocidos gracias a la televisión... En el actual contexto digital, que facilita el acceso a una miríada de contenidos culturales a través de Internet, se da una competencia tan amplia, que las artes escénicas no siempre cuentan con las circunstancias adecuadas para animar al público a encauzar su tiempo libre allende el ocio doméstico.

Pese a ello, paradójicamente, se ha producido un importante incremento en la afluencia de espectadores a representaciones teatrales desde 2008, dato que contrasta con el habitual desinterés por las mismas que manifiestan los medios de comunicación generalistas. Los espacios destinados a la cultura han sido relegados a horarios minoritarios dentro de la programación.

Esta investigación se propone evidenciar esta hipótesis a través del análisis de las diferentes parrillas de radio y televisión, así como de la prensa impresa y en línea.

Creemos que, aunque el público se ha encargado de frenar la tendencia descendente en la afluencia a los teatros, los medios de comunicación no han recogido suficientemente este nuevo contexto, perpetuando una situación discriminatoria, que contrasta con la de otras manifestaciones culturales como el cine o la música que sí hallan amplio eco.

Los medios de comunicación para masas son los verdaderos generadores y fuerzas motrices de la Opinión Pública, por lo que es imprescindible su colaboración para el desarrollo de la Cultura de un país, dentro de ella. Por tanto, el estudio de la divulgación, imprescindible para todo aquello que se considere acervo cultural (en nuestro caso, el teatro), redundará en la forja de una Opinión Pública experta y comprometida, que pueda avanzar por ese camino'.

El indudable éxito de algunas modalidades teatrales (musicales, monólogos de humor...) no debe hacernos bajar la guardia con respecto a la indiferencia con la que el teatro entendido como representación escénica in génere- es tratado, en su conjunto, por los Medios. Jerónimo López Mozo (Premio Nacional de Literatura Dramática en 1998)

\footnotetext{
1 El concepto de Opinión Pública ha sido teorizado por diversos autores, de entre los que queremos destacar a Cándido Monzón. Véase su obra Opinión Pública, Comunicación y Política. Tecnos. Madrid. 1996.
} 
reconoce el éxito de cierto tipo de teatro, en boga en la actualidad, pero alerta sobre el declive real de otros géneros teatrales:

\begin{abstract}
"He de recordar que, en el pasado, la amenaza afectaba a todo el teatro, porque el enemigo era exterior. Los momentos críticos se produjeron con el nacimiento del cine, primero, y de la televisión, después. De la alarma participaba toda la profesión. Pero ahora no sucede lo mismo. Afecta solo a una parte de ella. El aumento del número de espectadores y de las recaudaciones que dan pie al optimismo no alcanza a todos por igual. Es lógico que así sea. Los éxitos y los fracasos se reflejan de forma bien diferente en las cuentas de resultados. Tampoco ignoramos que determinados géneros dramáticos resultan más atractivos para el público que otros y que, en cada uno de ellos, no todos los espectáculos tienen igual acogida. Mientras unos locales cuelgan el cartel de no hay localidades, otros permanecen vacíos. No es agradable que eso suceda, pero lo es mucho menos que, en aras de ofrecer un balance positivo de la situación del teatro español, esa realidad se escamotee. Ese manto, que aparentemente cubre a todos, está a punto de conseguirlo. Hay una parte de nuestro teatro que vive al margen del triunfalismo reinante y que está abocado a su desaparición. Puede que sea inevitable. Pero haríamos mal los autores españoles en contribuir a ello negándonos a aceptar que el problema existe o fingiendo no verlo."2
\end{abstract}

\title{
Metodología
}

Por tratarse de una investigación inductiva (y de campo), se ha procedido al análisis de las diversas secciones y parrillas de programación de los medios de comunicación (televisión, radio y prensa) entre 1999 y 2009, principalmente. Se han baremado los resultados obtenidos en cada uno de los medios y se han analizado las encuestas del Ministerio de Cultura a los espectadores durante los últimos años. Nuestra intención ha sido realizar una aproximación a la realidad de los medios de comunicación españoles más generalistas. Debemos puntualizar que, en lo que respecta al teatro, Madrid y Barcelona reúnen el mayor número de escenarios y representaciones, lo que explica que hayamos prestado más atención a estas ciudades. Por cuestiones de importancia y volumen representativo, nos hemos centrado en la primera, capital teatral del país, incluyendo en nuestro estudio a los medios locales y autonómicos. También hemos muestreado los medios escritos barceloneses en nuestra investigación para corroborar tendencias a nivel nacional. Los datos empleados de estadísticas oficiales, a fecha actual, mediados de 2011, siguen siendo de 2007, ya que las Administraciones no los han actualizado, lo que da idea, una vez más de la escasa atención que se le presta al teatro incluso por parte de la Administración.

\section{Información sobre las Artes Escénicas ofrecida por los Medios de Comunicación Digital}

\subsection{Medios Televisivos}

Vamos a pasar, sucintamente, a describir los diversos Medios españoles, ya que esta investigación se halla hermanada con otras similares que se desarrollan en México (Universidad de Zacatecas) y Chile (Universidad de La Frontera), por lo que las explicaciones sobre los Medios, en cuanto a titularidad y perfil, son pertinentes y necesarias.

Existe una tradición de promoción puntual en las televisiones que se basa en invitar como entrevistado o como participante de algún programa a famosos actores con obra en cartel, quienes aprovechan la oportunidad para promocionar su trabajo.

2 LÓPEZ MOZO, J. "La invisibilidad del teatro español actual". Biblioteca Virtual Miguel de Cervantes. Consultada

el 27-12-10

Disponible

en wWw.cervantesvirtual.com/servlet/SirveObras/12482849778137196310846/p0000001.htm\#PagFin 


\subsubsection{La 1 de TVE}

La 1 es la cadena generalista de la Corporación (antes Ente Público) RTVE (Radio Televisión Española).

De titularidad estatal, tiene encomendada entre sus obligaciones ofrecer y garantizar el servicio público de radio y televisión, en el que se incluye la cobertura informativa de la actualidad cultural. No emite anuncios desde 2010.

TVE 1 ofrece unos espacios de perfil generalista con contenidos equilibrados considerados apropiados para la mayoría. Los contenidos de la otra cadena pública, La 2, y los de los canales temáticos, en cambio, han sido diseñados para un perfil más minoritario.

Por esa razón no es posible encontrar en esta cadena ningún espacio permanente referido a las artes escénicas. A veces, se ofrece en los magazines o servicios informativos alguna noticia puntual que tiene al teatro como protagonista, pero sólo si el acontecimiento tiene alguna relevancia concreta para el gran público: Un protagonista famoso, un éxito espectacular o una superproducción.

Dada su parrilla histórica, se colige que TVE 1 pone el acento en las series de producción propia, que resultan su prioridad. También el cine (tanto nacional como extranjero) está altamente representado en la programación con espacios a veces semanales, como Cine de Barrio -que hace un repaso histórico del cine español- o Cine Club -que presenta películas en versión original con subtítulos en español-, o espacios bisemanales (emitidos las madrugadas de jueves y domingo) como Cine de madrugada. También encontramos programas como Así se hizo, que, semanalmente, comenta los estrenos de cine de la semana, muestra visitas a rodajes y se emiten entrevistas a directores y actores de actualidad, tanto españoles como extranjeros.

En la nostalgia y muy atrás en el tiempo, queda el magnífico programa de teatro Estudio 1 (sucesor del muy ponderado Primera Fila) emitido casi ininterrumpidamente entre 1965 y 1985, en el que semanalmente se emitía una obra de teatro completa, inicialmente la noche de los domingos, y a principios de la década de los ochenta, los viernes. Gracias a programas como éste, la afición al teatro pudo cuajar en el espectador, especialmente en ciudades donde el teatro era (y es, aún) algo minoritario o excepcional.

Se trató de emitir de nuevo en el año 2000 y en el 2010 con una única obra por el momento: La viuda Valenciana (Lope de Vega).

Recordemos que cuando TVE comenzó en 1956 sus emisiones, casi todos los programas eran de producción propia y en directo (existían graves limitaciones técnicas para la grabación, que era efectuada en soporte cine) por lo que se emitían varias representaciones teatrales diarias. Programas como: Teatro de Familia, Gran Teatro, Estudio 3, Novela...

\subsubsection{La 2 (TVE)}

La 2 es el canal encargado de dar respuesta a las inquietudes de los diversos sectores culturales y creativos de la sociedad que no ven atendidas sus preferencias en la programación de TVE 1. No emite anuncios desde 2010.

Cuenta con variados espacios culturales de producción propia, con frecuencia ubicados en horarios de madrugada y última hora, aunque podemos encontrarlos en horarios más generalistas en el canal temático "Cultural-es" del ente RTVE en TDT.

En La 2 encontrábamos el mejor ejemplo de lo que consideramos el modelo deseable de espacio sobre teatro: La Mandrágora. Revista teatral de La 2. Por desgracia, este valiente espacio pereció en 2009, privando a la parrilla del único programa de entre todas las cadenas estatales y privadas que se dedicaba exclusivamente al teatro en todas sus 
manifestaciones y tendencias. Se trataba de un espacio semanal emitido los viernes a las doce de la noche, donde era posible encontrar todo lo que de relevancia se ofrecía en el panorama nacional de las artes escénicas. Incluía entrevistas, resúmenes audiovisuales de la trayectoria del entrevistado, reportajes con los ensayos de los estrenos y seguimientos de los montajes en el escenario. Lamentamos que este interesante camino fuera abandonado, pues representaba la única apuesta decidida por llevar el teatro a los hogares y así estimular la asistencia a los auditorios.

Aunque la mayoría de los programas culturales de La 2 se ocupa del mundo de la literatura (Página 2, Nostromo), sobrevive un veterano espacio que incluye al teatro entre sus inquietudes. Se trata de Metrópolis (en antena desde 1985), un espacio de cultura dedicado a las últimas tendencias en el campo de la creación artística. Se emite los viernes a las doce de la noche. En él se ofrecen excelentes primicias teatrales, aunque en sus contenidos suelen predominar exposiciones de artistas de vanguardia, muestras escénicas, improvisaciones y experimentación audiovisual. También los espacios Miradas 2 y La Noche Temática, con monográficos sobre temas culturales, incluyen teatro (generalmente experimental entre sus reportajes de producción propia).

\subsubsection{Antena 3}

Aunque el público objetivo de esta cadena, formado por clases medias urbanas de nivel cultural medio y alto, responde al perfil de potenciales espectadores de teatro, apenas encontramos espacios que dediquen algún contenido a las artes escénicas. La presencia del teatro se limita a las noticias recogidas en magazines y programas de sociedad, centradas en la asistencia o participación en una obra de teatro de personajes reconocibles por la sociedad; las noticias emitidas en la sección cultural de las diferentes ediciones de Antena 3 Noticias reciben un tratamiento más sobrio e informativo, aunque sólo tienen cabida los acontecimientos más destacados.

La cadena apuesta por llenar su parrilla con series extranjeras (no sólo norteamericanas), series de producción propia y magazines, dejando la información cultural para momentos puntuales de los informativos y como anécdotas dentro de otros programas de tertulia.

Con la llegada de la TDT (2009) encontramos una oferta de contenidos mucho más diversificada, pero el teatro, pese al cambio de tendencia apuntado, no consigue protagonizar ningún espacio específico.

Hasta 2010, Antena 3 ofrecía un programa semanal llamado Casa de América donde se recogía lo más destacado del mundo del arte y el espectáculo con una vocación claramente iberoamericana. Incluía una agenda semanal de acontecimientos culturales y de ocio en España. La información sobre teatro tenía cierta presencia en el espacio, pero era mínima en comparación con otras manifestaciones artísticas.

El resto de canales del Grupo Antena 3 no tiene ningún programa que incluya información específica sobre las artes escénicas, y son los espacios de actualidad y los informativos (como "mira-t" del canal local para la Comunidad de Madrid: Ver-T) los que incluyen noticias sobre cultura como parte de la actualidad diaria.

Por lo tanto, podemos decir que los contenidos sobre información cultural incluyen alguna reseña sobre las representaciones teatrales que consideran de relevancia, aunque no siempre sea por los méritos del proyecto sino, a veces, por razones exclusivamente oportunistas o anecdóticas (alguna circunstancia de la representación coincide con un acontecimiento de actualidad).

En cambio, sí existen programas específicos de actualidad sobre cine.

\subsubsection{Canal + y Digital +}


Canal + y su plataforma Digital + no cuentan con ningún programa dedicado exclusivamente al teatro. Los temas que Canal + aborda en mayor profundidad son el cine, el deporte, las series norteamericanas, las noticias, la música, los documentales y los programas infantiles. Se trata de una programación generalista que busca captar el mayor número de clientes posible, ya que estamos ante una cadena de pago.

La que fuera históricamente la primera cadena de pago en España muestra interés por los temas culturales y por los espectáculos. Sin embargo, el teatro se encuentra relegado a un papel secundario, hallando sólo cabida en los informativos $y$, tangencialmente, en algunos programas culturales por medio de entrevistas a algún personaje vinculado al mundo teatral (generalmente actores que son entrevistados exclusivamente por su aparición en una película de reciente estreno).

El perfil de la audiencia de la plataforma de pago refleja un tipo de espectador con inquietudes culturales, susceptible de acudir a los teatros si se le da la oportunidad de recibir información sobre las representaciones teatrales.

La adquisición del 22 \% de esta cadena y del resto de cadenas de Sogecable por Telecinco no supone, en principio, cambio alguno en cuanto al interés por el teatro en la programación.

\subsubsection{Telecinco}

El teatro cuenta con una reducida presencia en este canal. El plato fuerte de la programación son los realities (telerrealidad), los programas de sociedad, los programas de cierre de noche, el cine y las series de producción propia.

Las menciones al teatro se limitan a breves y esporádicas informaciones en magazines de la cadena o en informativos. Parece evidente que cadena, anunciantes y público objetivo comparten cierta falta de interés por el teatro.

En el resto de canales de Gestevisión Telecinco en TDT la situación es similar.

La compra del $22 \%$ de Canal +, y de la cadena Cuatro en su totalidad, no va a cambiar la línea editorial, ya que las razones de tales adquisiciones pertenecieron al terreno puramente económico, buscándose acumular una mayor cuota de pantalla.

Pese a la escasa presencia del teatro, debemos reconocer que diversos programas de la cadena han hecho las veces de caladero de actores e intérpretes de musicales, una modalidad teatral en auge.

\subsubsection{Cuatro}

Esta cadena nació en 2005 con la intención de presentarse como alternativa al panorama televisivo español. Apostó por series norteamericanas de éxito garantizado por sus resultados en otros países. Hizo un hueco en su parrilla al deporte y a los concursos de aventura, a los realities, docu-realities y a los talk shows (de entrevistas y humor). También se centró en programas de actualidad específicos para música y cine, pero no para teatro.

Su absorción por Gestevisión Telecinco no parece que vaya a influir en la programación, por lo que tampoco se espera un aumento de la presencia del teatro en los contenidos.

Al igual que Tele 5, Cuatro ha prestado un reseñable servicio al teatro musical con programas que han permitido expresarse a futuros actores a través de la danza y el drama. Esta cadena ha sido adquirida por Tele 5 en 2010.

\subsubsection{La Sexta}


Nacida en 2006 y última analógica creada antes del apagón analógico que forzó a la emigración a la TDT, esta cadena buscaba también ofrecer un planteamiento alternativo a la oferta consolidada de Antena 3 y Tele 5 en el ámbito de las privadas.

La inicial apuesta por el deporte y las series norteamericanas de éxito tuvo su contrapunto en una fórmula innovadora basada en el humor, con talk shows y programas de cierre de noche. Se buscaba un público joven y transgresor, pero en este caso tampoco se consideró apropiado ofrecer una programación específica sobre teatro, incluyéndose la información sobre las artes escénicas en los demás espacios.

No obstante, hemos de reconocer el esfuerzo de la cadena por ofrecerse como medio de difusión de nuevas manifestaciones culturales sobre el escenario, como el mundo del monólogo y la improvisación. Su relación con el teatro es lo suficientemente estrecha como para tener en cuenta esta modalidad de éxito en los últimos años.

Hubo un intento de fusión con Cuatro en el segundo trimestre de 2009 que no fructificó, por lo que se pactó posteriormente con Antena 3.

La unión Antena 3-La Sexta no supondrá desgraciadamente, a priori, una mayor presencia del teatro en las nuevas parrillas.

\subsubsection{TeleMadrid}

Esta cadena de televisión autonómica se caracteriza por una programación con un alto porcentaje de horas de producción propia en directo, lo que ayuda a abaratar costes. A través de la elaboración de programas de reportajes y noticias, busca convertir en protagonista al ciudadano de la Comunidad de Madrid. Utiliza la fórmula del magazine y del reportaje en directo para comentar la actualidad, lo que permite acceder a información sobre estrenos (de cine y teatro) en Madrid.

También hay un mini-espacio en horario de máxima audiencia llamado Madrid se mueve, donde se hace una breve reseña con imágenes, voz en off, y un pequeño texto indicando lugar y horario, sobre teatro, danza, circo, etc., excluyendo al cine, quien ya tiene sus propios espacios.

La séptima arte, como decíamos, sí tiene una cobertura estable en la programación, ya que, allende el entretenimiento, las proyecciones de películas incluyen desde un repaso histórico a la trayectoria del director, hasta un reportaje sobre la elaboración de la película pasando por cortes de la misma. También encontramos espacios dedicados en exclusiva a la Historia del Cine.

También se emite un programa sobre literatura en horario de madrugada.

En relación al teatro, no hallamos ningún programa específicamente dedicado a él. Son los informativos los que cubren la actualidad teatral, desde los aspectos más técnicos (como los decorados o los presupuestos), hasta el elenco de artistas que trabajan en las obras, pero siempre desde la actualidad plasmada en las carteleras; otros programas incluyen a menudo pequeños reportajes alusivos al teatro. Estos espacios son, a menudo, entrevistas con actores del momento que, con motivo de un estreno, hablan de su vida privada o profesional, pero sin aludir nunca a los aspectos técnicos o artísticos de las representaciones.

Existe una segunda cadena autonómica, LaOtra, que incluye varios programas específicos sobre música y vídeos musicales. Aunque se presta atención a la danza experimental, el teatro ocupa, de nuevo, un papel secundario.

\subsection{Medios Radiofónicos}

Es cierto que la mayoría de las emisoras a continuación reseñadas, como fórmula promocional con ciertas representaciones, sortean dentro de algunos programas (en 
general, aunque no exclusivamente, de tertulia y programas-río, que van desde las 10 ó 12 del mediodía hasta el informativo de las 13.30 ó 14.00 ó 14.30 horas) entradas como premio a respuestas a preguntas sencillas que los espectadores han de resolver.

\subsubsection{R.N.E}

Radio Nacional Española (R.N.E.) es una emisora estatal comprometida con el mundo de la cultura que cuenta, incluso, con una Unidad de Cooperación Cultural. No emite anuncios. La cultura tiene un lugar muy destacado en su programación, pero aunque se utilizaba el término "teatro" en el nombre de uno de sus programas, Vamos al teatro (cuyo último programa se emitió en octubre de 2009), era un título en parte engañoso, aunque sin mala intención, puesto que se refería a las obras musicales compuestas para teatro como el ballet o las coreografías, atingiendo, casi exclusivamente, piezas teatrales experimentales. Pero si hay un espacio dedicado al mundo de la cultura que trata específicamente el tema del teatro, ése es El ojo crítico.

El ojo crítico, de una hora de duración, se emite de lunes a viernes a partir de las siete de la tarde (anteriormente se emitía a las diez de la noche). Este programa es un espacio informativo donde se muestra lo más destacado de la actualidad cultural del día mediante reportajes, entrevistas, conexiones en directo con los colaboradores del programa presentes en conciertos, estrenos teatrales y cinematográficos dedicando una especial atención a las novedades editoriales. Para la información referente al mundo del teatro, se elaboran reportajes, sin embargo, éstos son esporádicos y minoritarios en relación con los de otros temas culturales. El programa concede anualmente los premios que llevan su nombre, destinados a reconocer el trabajo de jóvenes artistas de todas las disciplinas creativas, incluyendo un premio específico para el teatro.

\subsubsection{M-80 Radio}

M-80 (del Grupo PRISA) ha desarrollado desde hace años la fórmula que combina música y noticias.

Se plantea prestar especial atención a la historia de la música contemporánea, emitiendo éxitos de las últimas décadas mientras se da espacio a los nuevos valores.

La mención al teatro aparece en los servicios informativos si la actualidad lo requiere. De lunes a viernes los boletines son de carácter general, pero durante los sábados y domingos se busca atender a la oferta de ocio, dentro de la que se incluye el teatro. Sigue sin existir ninguna sección específica, como tampoco la hay sobre cine. Se cubren sobre todo informaciones sobre música.

Esta emisora privada pertenece a Unión Radio, al igual que la cadena SER.

\subsubsection{Cadena SER}

La Sociedad Española de Radiodifusión (SER) pertenece al Grupo PRISA. No tiene una línea editorial definida en relación al teatro: SU apoyo o silencio se basa en diversos factores relacionados con el ámbito mercantil. Se suele conceder prioridad a los montajes que tienen publicidad contratada con la Cadena SER. La colaboración con las obras se limitará a críticas y entrevistas insertadas en los programas informativos y magazines como Hoy por hoy, Hoy por hoy Madrid, La ventana y A vivir que son dos días, además de la sección de cultura y espectáculos de los servicios informativos. Primarán las críticas que estimulen la curiosidad de los oyentes y su asistencia a las salas. La empresa productora del proyecto teatral objeto de la crítica siempre tendrá derecho a intervenir en el programa. 
Esta emisora privada pertenece a Unión Radio, al igual que M-80 Radio.

\subsubsection{Onda Cero}

Esta emisora privada perteneciente al Grupo Antena 3 se propone ofrecer una amplia cobertura sobre temas culturales, entre los cuales se incluye, como no podía ser de otra manera, el teatro.

No obstante, en este momento la cadena no cuenta con ningún espacio específicamente teatral. La larga duración de los programas de la emisora hace inviable dedicar uno al teatro, ya que sigue siendo un espectáculo relativamente minoritario. Sin embargo, éste tiene su hueco en las secciones culturales de los espacios existentes, siempre que el estreno tenga relevancia.

\subsubsection{La COPE (Cadena de Ondas Populares Españolas)}

Depende de la Conferencia Episcopal.

Destacan algunos programas en que se regalan entradas teatrales aprovechando la presencia de algún invitado relacionado con dicha obra, quien las ofrece al público durante su intervención.

Destaca el programa cultural, con tertulia e invitados La Luna, con horario de 01.00 a 04.00 de la madrugada. En él se suelen entrevistar semanalmente a varios protagonistas de la escena madrileña.

También los mediodías La gran manzana suele sortear entradas entre los oyentes cedidas (a cambio de la publicidad que conlleva) por las productoras teatrales.

\subsubsection{Radio España (emisora desaparecida en 2001)}

Radio España, nacida en 1924, fue una emisora de las últimas que emitía exclusivamente en Onda Media en la ciudad de Madrid. Hemos considerado interesante reseñarla pues mantuvo siempre su apoyo al teatro. Su relación con el fomento de la asistencia al teatro nace de una organización llamada Círculo Radio España, que permitía a los oyentes, por una cantidad anual de dinero, pasarse semanalmente por la emisora para recoger dos entradas de una obra de teatro. Se trataba de un intercambio: los teatros ofrecían un número concreto de entradas a la cadena y ésta se comprometía a introducir publicidad de los mismos y sus obras en cartel de forma gratuita.

\subsection{Medios Escritos}

\subsubsection{El Mundo}

El diario El Mundo da una cobertura considerable a las artes escénicas en todas sus manifestaciones. Diariamente, en el apartado Cultura, se informa de los estrenos, la calidad de las representaciones, aparecen entrevistas a los protagonistas de obras o se informa sobre las cuestiones económico-administrativas de esta actividad. Una información similar se incluye en la sección de la Comunidad de Madrid referida a la actualidad autonómica. Además, el diario emplea las entrevistas como instrumento para atraer la atención de los espectadores, publicando reportajes en los que se da cuenta de la trayectoria profesional, la vida, la carrera artística o los éxitos cosechados por los autores, artistas o directores de determinadas obras.

La sección-suplemento Metrópoli (que funciona como sección de elmundo.es y como suplemento digital independiente) subtitulada como La Guía de Madrid, incluye un 
apartado llamado Teatro con toda la información referida a los estrenos, el éxito de las obras, comentarios, entrevistas, imágenes... e incluye espectáculos de danza. Asimismo, dedica un apartado a lo que denomina Espacios Alternativos.

Esta sección también tiene un buscador de teatros y obras para la ciudad de Madrid, donde indica horario y precio de las entradas.

La revista El Cultural tuvo en su día una edición impresa que se entregaba como suplemento semanal de El Mundo, pero actualmente funciona de forma independiente. En su edición digital hay una sección fija denominada Escenarios dedicada al teatro y a la danza, con reseñas, imágenes y comentarios de cada obra en cartel considerada de cierta relevancia. Incluso existe un apartado denominado Recomendados, donde El Cultural sugiere un estreno concreto.

\subsubsection{El País}

Perteneciente al Grupo PRISA. Como norma general, el diario concede poco espacio al teatro, salvo que tenga lugar algún acontecimiento importante en el panorama teatral.

Por su parte, el suplemento Babelia (presente como sección en la edición digital), dedicado a la cultura -pero con vocación de cajón de sastre de cualquier tema relacionado con la creatividad- contiene secciones sobre Entrevistas, Reportajes, Libros, Arte, Música, Arquitectura, Cine, etc., apareciendo ocasionalmente una reseña llamada Puro Teatro con información sobre una representación teatral considerada relevante.

El resto de los suplementos de El País, en su edición impresa, no contempla información sobre teatro o artes escénicas de forma permanente. Por el contrario, El País Semanal (tanto en su edición digital como en la edición impresa) vuelve a incluir la sección Babelia a la que se accede con un enlace.

El País, sin embargo, en su edición para Madrid digital o impresa sí recoge, varias veces a la semana, referencias de alguna de las obras que se estrenan en la capital en una sección denominada Escena.

\subsection{3 $A B C$}

La conclusión que se obtiene del seguimiento a este medio es que ha aumentado su interés por el teatro en los últimos años. Ahora el espacio dedicado a Cultura se reparte entre Cine, Música, Literatura, Teatro, Arqueología, Arte y El $A B C$ de la crítica, abandonando la nomenclatura Espectáculos que incluía noticas sobre cine pero sólo escuetas críticas sobre teatro. Ahora, el epígrafe Cultura desarrolla informaciones con mayor calado y diversidad.

La sección de Cultura proporciona el mismo espacio a sus apartados. En el referente a Teatro hay noticias, estrenos, entrevistas...

En el denominado El $A B C$ de la crítica también se incluyen críticas teatrales.

La revista XL Semanal, que en su edición impresa se entrega como suplemento semanal con el diario $A B C$, sólo dedica espacio al cine y a sus estrenos, en una sección denominada Hoy Cinema. En su versión digital encontramos, además, un buscador de salas por provincias, pero sólo para cine.

\subsubsection{La Razón}

Encontramos la sección denominada Cultura con varias subsecciones llamadas Cultura, Espectáculos, Libros y Cultura Multimedia. Es en Espectáculos donde es posible encontrar, esporádicamente, alguna noticia sobre teatro y artes escénicas, pero lo habitual es ver artículos sólo sobre cine. Una rareza interesante es un blog en esta misma sección 
denominado Entre bambalíneas que trata contenidos sobre danza, actividad que, pese a realizarse sobre un escenario, no es nuestro objeto de investigación.

\subsubsection{Público}

También aquí encontramos una sección dedicada a la Cultura, conformada por tres subsecciones: Noticias, Cartelera de cine y Vídeos. Sólo la subsección Noticias contempla eventualmente la posibilidad de incluir una información relacionada con el teatro o las artes escénicas, aunque no con un apartado propio sino dentro de una miscelánea: también son incluidos en Noticias artículos sobre Cine, Libros, Internet, Música, Exposiciones, Nuevas Tecnologías, Curiosidades...

\subsubsection{El Periódico de Catalunya}

En la sección Cultura casi todos los días se muestra alguna noticia o crítica relacionada con la actualidad del teatro y las artes escénicas. La sección funciona como un mosaico disperso de la actualidad. Encontramos una amplia panoplia de subtítulos que incluyen información muy diversa, entre la que puede encontrarse alguna noticia que hable de la actualidad teatral.

\subsubsection{La Vanguardia}

Diario editado en Barcelona.

En la sección Cultura no hay subsecciones ni subtítulos, por lo que la relación de noticias se presenta de forma aún más caótica que en el otro gran diario de Barcelona, El Periódico de Catalunya.

\subsubsection{Fotogramas}

La revista cinematográfica Fotogramas no dispone de una sección dedicada al teatro y las artes escénicas en nuestros días, pues su temática es fundamentalmente cinematográfica; anteriormente recogía pequeñas pinceladas sobre lo que acontecía en terrenos no estrictamente relacionados con el cine en una sección denominada Flash compuesta por noticias variadas sobre la actualidad artística en general: contenía noticias sobre teatro, musicales, danza, espectáculos... Actualmente la sección ha desaparecido y la ubicada en su lugar se denomina Noticias y se refiere sólo a la actualidad relacionada con el cine.

\subsubsection{La Teatral}

Revista nacida en 2003 y dedicada a la actualidad teatral en Andalucía, hoy es una referencia en todo el ámbito escénico nacional. En marzo de 2009 La Teatral crece con una nueva publicación de carácter mensual denominada La Express y que tiene un planteamiento cercano al de una agenda de ocio, con información reciente y recomendaciones para el tiempo libre, dejando para La Teatral el análisis y la información. Ambas pretenden encontrar nuevos públicos y, al mismo tiempo, ser un apoyo a los proyectos emprendedores y a la iniciativa privada, el circo, el teatro de calle, el teatro infantil, los títeres, la dramaturgia y las artes escénicas en general, incluyendo a los profesionales de campo (iluminadores, escenógrafos, distribuidores, coreógrafos...).

\subsubsection{Noticias Teatrales}


Web que funciona como una Gaceta. Publica reseñas de estrenos, calendarios e itinerarios de compañías, horarios, precios, comentarios críticos, opiniones, entrevistas a autores, directores y actores, talleres y cursos, libros y revistas, textos teatrales cedidos por los autores para la práctica de la interpretación; hay un foro, un libro de visitas con posibilidad de dejar un comentario, un archivo documental, noticias de última hora y el sitio, además, acepta información, noticias y gacetillas enviadas por los internautas, las propias compañías, actores, directores, productores o cualquiera que le interese el mundo de las artes escénicas. Todo se publica siempre que cumpla unas normas descritas por los editores en dicha página de manera clara.

Es un espacio vivo en el que todo aquel interesado en el teatro puede encontrar y aportar información sobre actualidad teatral, no sólo de España sino de todo el mundo, aunque el hecho de publicarse en español hace que sea más viable encontrar información casi exclusivamente de países de habla hispana. La página tiene un Apartado de Correos en Madrid al que enviar los textos e imágenes y multitud de información, renovada los días 1 y 15 de cada mes.

La información sobre Madrid, lógicamente, es la más abundante. No incluye publicidad, pues tal y como explica su editor, Salvador Enríquez, esta página no tiene ningún fin comercial, sólo la difusión de las actividades escénicas.

\section{Resultado de la prospectiva relativa a la información existente sobre las Artes Escénicas en los Medios de Comunicación Digital}

\subsection{Resultado de la prospectiva en los Medios Televisivos}

Los medios televisivos no aportan gran cantidad de espacios para la difusión de las artes escénicas.

La excepción es La 2, cadena pública que no está sujeta a las obsesiones mercantilistas de la competencia. Su objetivo es ser un medio de difusión cultural, por lo que busca ampliar la base de su oferta a todos los ámbitos creativos que se puedan desarrollar en nuestro país. Se busca una relación bidireccional en la que el ciudadano tenga acceso a todas las opciones creativas y el responsable la oportunidad de hacer visibles los proyectos culturales al ciudadano. Además de un programa específico sólo para teatro y artes escénicas, hay diversos programas que incluyen informaciones periódicas sobre teatro entre sus reportajes y noticias de actualidad.

Muchos de estos programas se pueden ver en el canal temático cultural-es.

\subsection{Resultado de la prospectiva en los Medios Radiofónicos}

Se presenta el mismo binomio que con las televisiones, sustituyendo en este caso RNE a La 2 como emisora responsable de la difusión de la cultura en las ondas.

Mantiene un programa informativo rico en opciones que diversifica sus noticias, poniendo al teatro al mismo nivel que las demás manifestaciones culturales. RNE realiza entrevistas y cubre los estrenos teatrales, de la misma forma que haría con conciertos, estrenos de cine o la presentación de una novedad editorial. A esto se suma la entrega anual del galardón El ojo crítico, homónimo a uno de los programas de la cadena.

Entre los medios privados destaca la cadena SER, en la que se realizan críticas teatrales de aquellas obras que tienen convenios publicitarios con la emisora. En los magazines se incluyen reseñas y comentarios que animan a acudir a ver esas obras.

Onda Cero también recoge con cierta frecuencia noticias sobre teatro y La COPE oferta cultura a altas horas de la madrugada.

El mejor modelo promocional era el empleado por Radio España. 


\subsection{Resultado de la prospectiva en los Medios Escritos}

Sólo revistas y páginas web especializadas se hacen eco en extensión de la actualidad teatral.

Puede considerarse una excepción el diario El Mundo, que, pese a no estar obligado a ofrecer ninguna cobertura cultural especial, se esmera en su edición digital en atender la actualidad de las artes escénicas. Incluye cuidadas secciones, tanto en el propio diario como en las revistas digitales, nacidas como suplementos a la edición impresa y que ya tienen vida propia en la Red.

Es obligado valorar esta excepción, dado el silencio general de los medios privados generalistas por la actualidad teatral. La paradoja surge por tratarse de un medio de comunicación privado, que debe pensar en sus intereses económicos, por lo que su apuesta por el teatro indica que percibe "algo" que los demás medios privados no captan y que permite a esta cabecera ser la puntera en asuntos teatrales.

\section{Datos recogidos en las últimas estadísticas culturales oficiales disponibles, realizadas por el Ministerio de Cultura}

\subsection{Encuesta de prácticas y hábitos culturales en España. 2006-2007, del conjunto de la población española}

3.1.1 Personas del conjunto de la población española que realizaron determinadas actividades culturales). 2006-2007 (En porcentaje de la población total).

Figura 1:

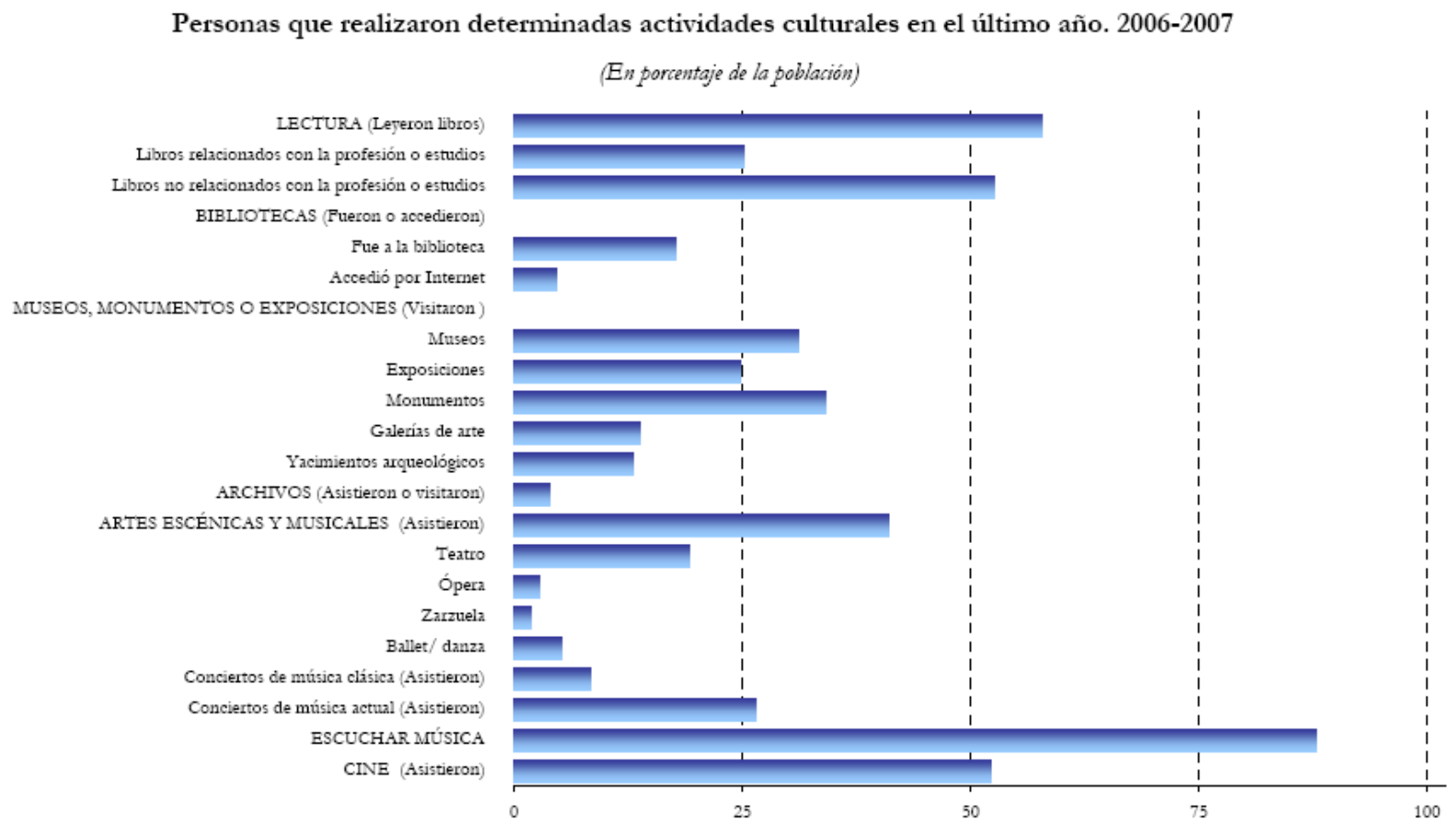

Fuente: Ministerio de Cultura 
Resumen: Escuchar Música $(87,9)$, Leer Libros $(57,7)$, Ir al Cine $(52,1)$, Ir a Ver Artes Escénicas y Musicales sin especificar $(40,9)$, Monumentos $(34,1)$, Museos $(31,2)$, Conciertos Música Actual $(26,4)$, Exposiciones $(24,7)$, Ir al Teatro, específicamente $(19,1)$, Asistir a Bibliotecas $(17,6)$, Asistir a Conciertos de Música Clásica $(8,4)$, Asistir al Ballet o la Danza $(5,1)$, Acceder a Bibliotecas por Internet $(4,6)$, Asistir a Archivos (3,9), Asistir a una Ópera $(2,7)$ y Asistir a una Zarzuela $(1,9)$.

El porcentaje de Ir a Ver Artes Escénicas y Musicales sin especificar se coloca en $4^{\circ}$ lugar de las actividades globales, por el gran porcentaje que aporta $(26,4)$ el asistir a Conciertos de Música Actual, que en esta estadística se incluye como un apartado de las Artes Escénicas cuando no lo es, la acción transcurre en un escenario, pero no puede considerarse actividad escénica. Por eso el dato es engañoso. Hay que ir al apartado específico de Teatro para darnos cuenta de la realidad $(19,1)$.

Sobre la base del análisis de la gráfica anterior inferimos que la asistencia al teatro supone la octava actividad cultural preferida por el público encuestado, llegando ésta a un $20 \%$. Aún así el teatro queda lejos de otras manifestaciones culturales. Sólo uno de cada cinco individuos va al teatro, frente a los porcentajes más altos como escuchar música (con un $85 \%$ ) o el disfrute de un buen libro (prácticamente un 60\%).

Con frecuencia se ha argumentado que el elevado precio de las entradas coloca al teatro en desventaja con respecto a otras artes. Pero ese hecho no puede distraernos de la realidad, que descansa en otros factores, ya que el coste no ha sido un elemento disuasorio para otras formas de ocio de masas.

3.1.2 Personas que han realizado actividades artísticas en 2006-2007 (En porcentaje de la población total).

Figura 2:

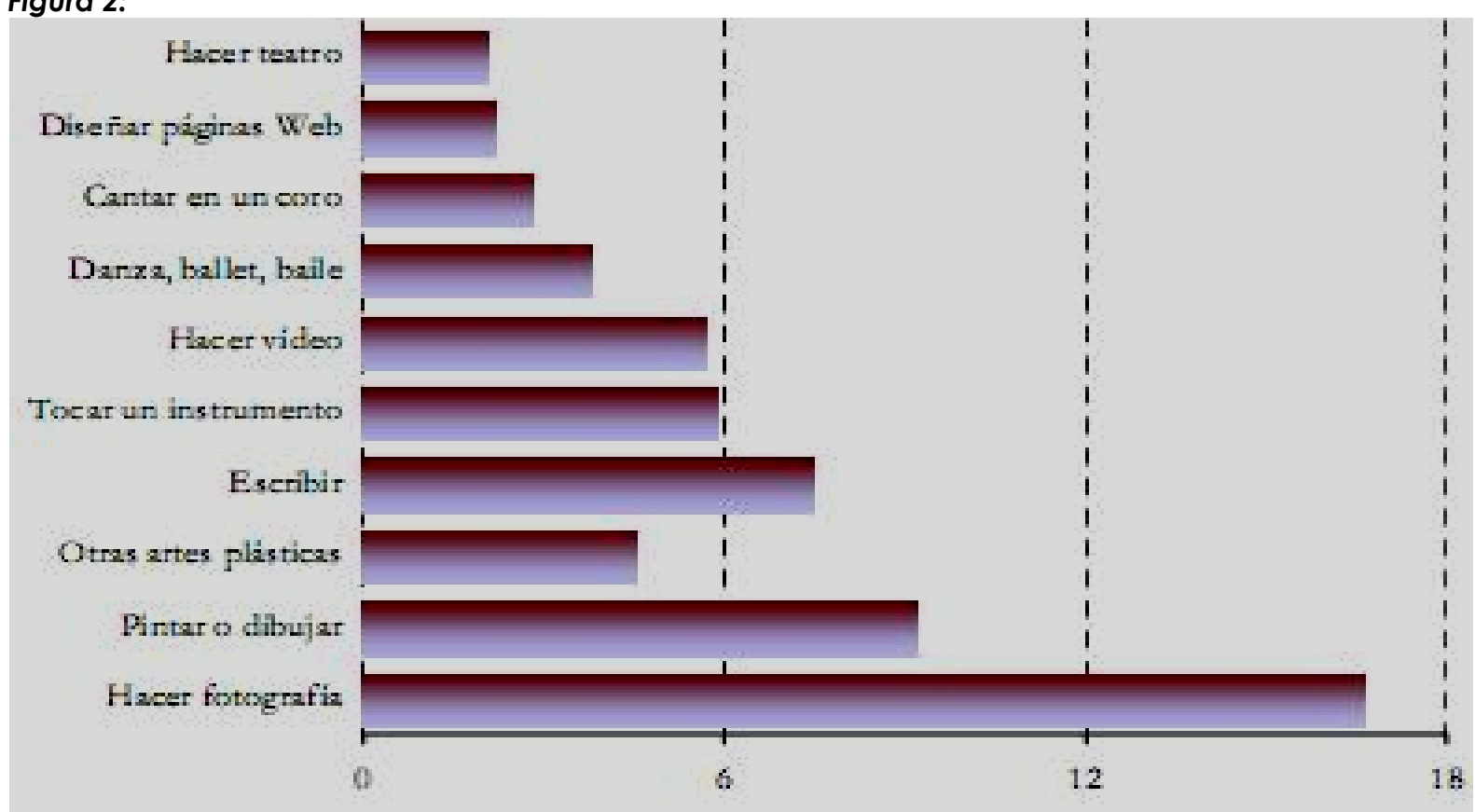

Fuente: Ministerio de Cultura 
Resumen: Hacer Fotografía (16,6), Pintar o Dibujar (9,2), Escribir $(7,5)$, Tocar un Instrumento Musical (5,9), Hacer Vídeos (5,7), Otras Artes Plásticas $(4,5)$, Hacer Danza, Ballet, Baile $(3,8)$, Cantar en un Coro $(2,8)$, Diseñar Pág. Web $(2,2)$ y Hacer Teatro $(2,1)$.

3.1.3 Personas según la asistencia al teatro en 2006-2007 (En porcentaje de la población total de mayores de 15 años).

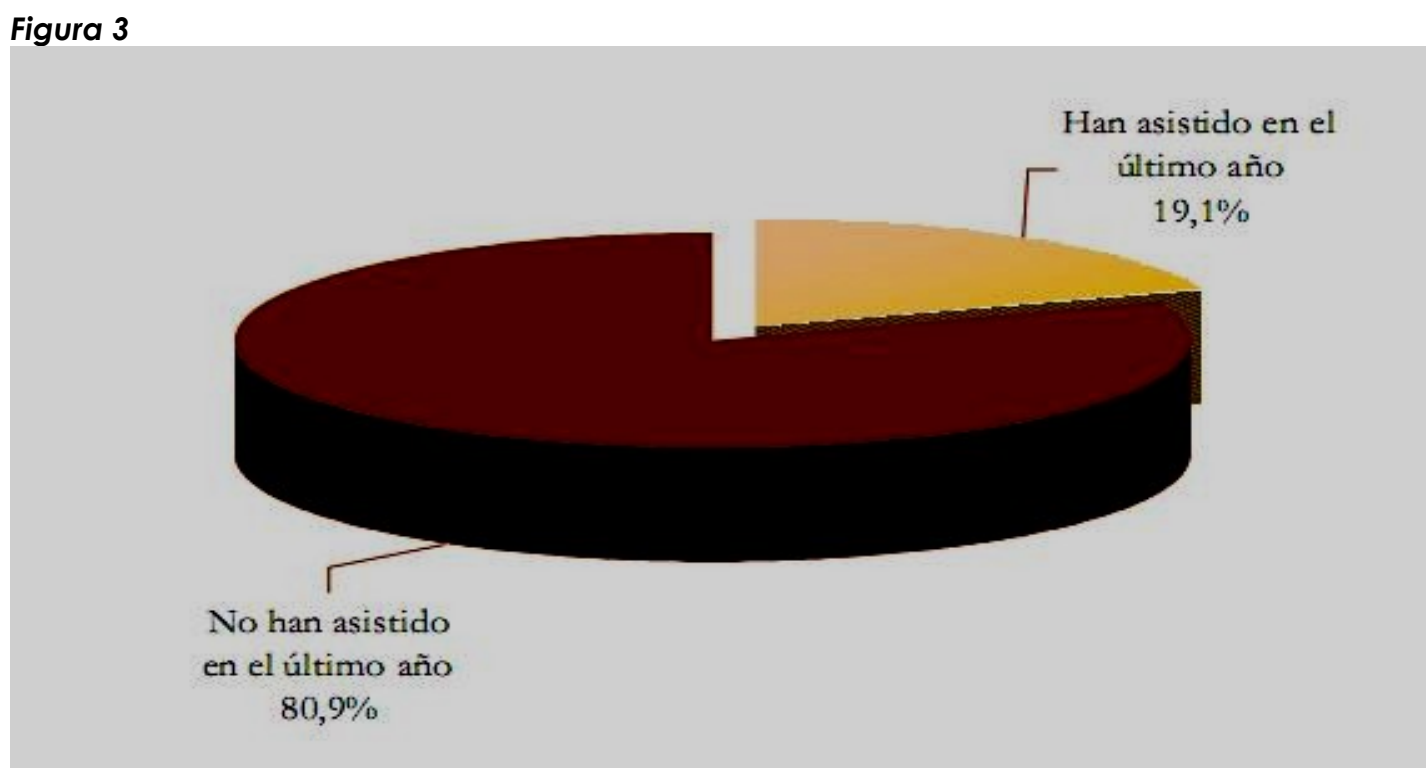

Fuente: Ministerio de Cultura

Resumen: Han asistido al teatro $(19,1)$ y No han asistido al teatro $(80,9)$.

3.1.4 Personas según la asistencia al teatro en 2006-2007 (En porcentaje de la población de cada sexo, grupo de edad, situación vital y nivel de estudios, mayores de 15 años). 


\section{Figura 4}

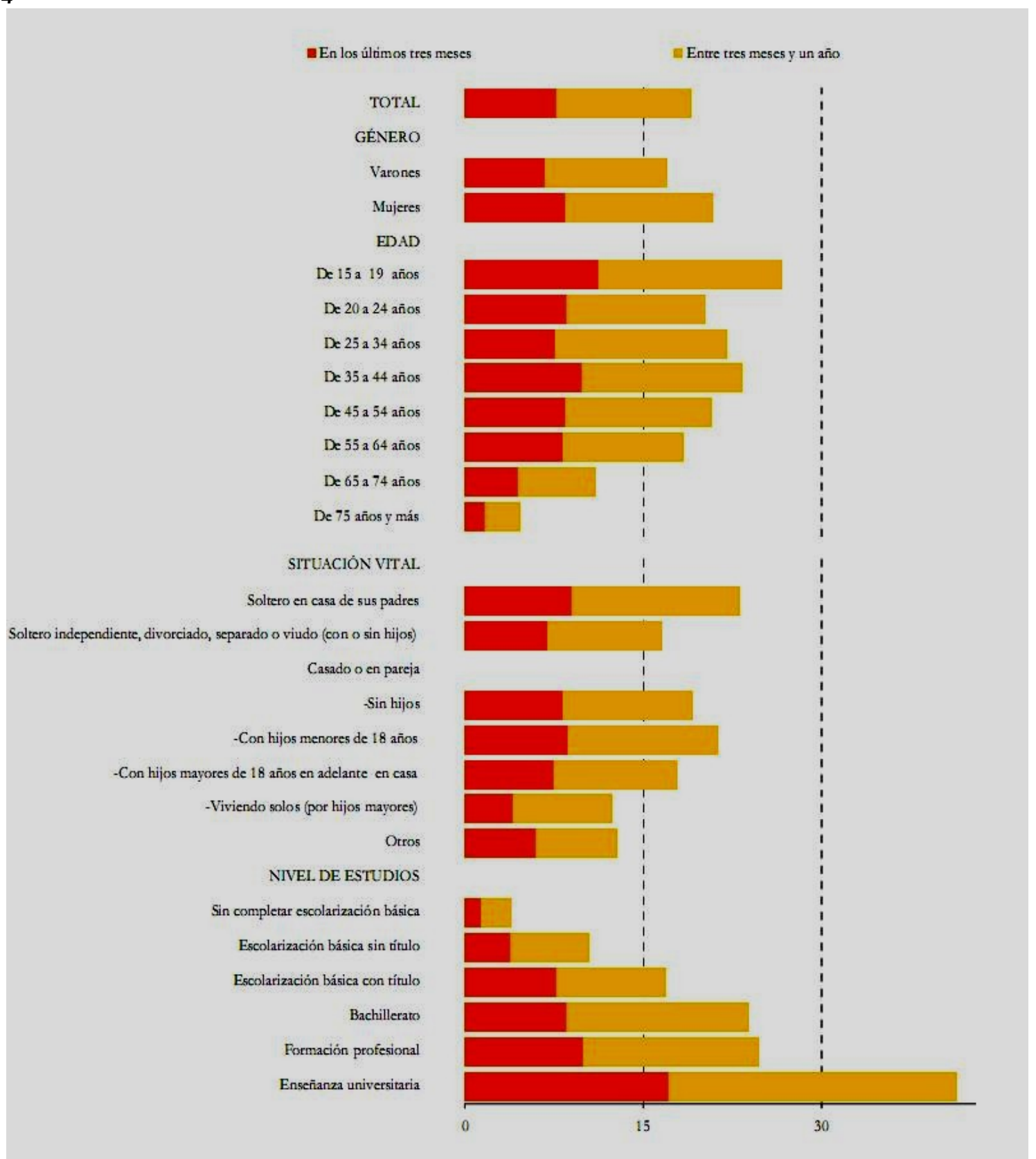

Fuente: Ministerio de Cultura

Resumen: Enseñanza Universitaria (17,1), De 15 a 19 años (11,3), Formación Profesional (9,9), De 35 a 44 años (9,8), Soltero en casa con sus padres $(9,0)$, Casado o con pareja y con hijos menores de 18 años (8,7), Bachillerato (8,6), De 25 a 34 años (8,6), De 45 a 54 años (8,5), Mujeres (8,6), De 20 a 24 años (8,5), Casado sin hijos, (8,2), De 55 a 64 años $(7,9)$, Casados con hijos mayores de 18 años viviendo en casa $(7,7)$, Escolarización básica con título $(7,5)$, Soltero independiente, divorciado, separado o viudo (con o sin hijos) $(7,0)$, Varones (6,8), Otros (6,0), Viviendo solos (por hijos mayores) $(4,1)$, De 65 a 74 años $(4,0)$, Escolarización básica sin título $(3,9)$, De 75 años y más $(1,7)$ y Sin completar escolarización básica $(1,4)$. 
3.1.5 Personas que han asistido al teatro en 2006-2007, según el género teatral de la última vez que asistieron en porcentaje de asistentes en un año, mayores de 15 años).

\section{Figura 5}

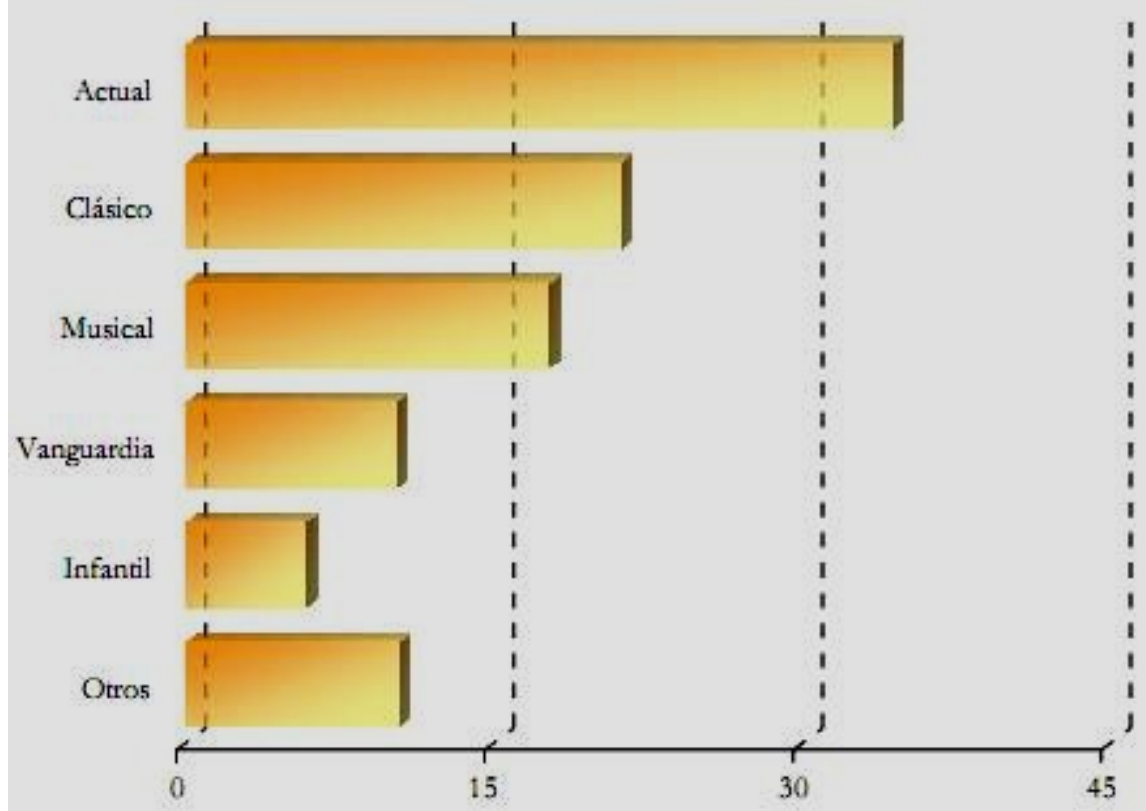

Fuente: Ministerio de Cultura

Resumen: Actual (34,4), Clásico (21,2), Musical (17,7), Otros (10,4), De Vanguardia (10,3) e Infantil $(5,9)$.

3. 1.6 Personas que han asistido al teatro en 2006-2007 según el tipo de entrada de la última vez que asistieron (En porcentaje de los asistentes en un año, mayores de 15 años).

\section{Figura 6}

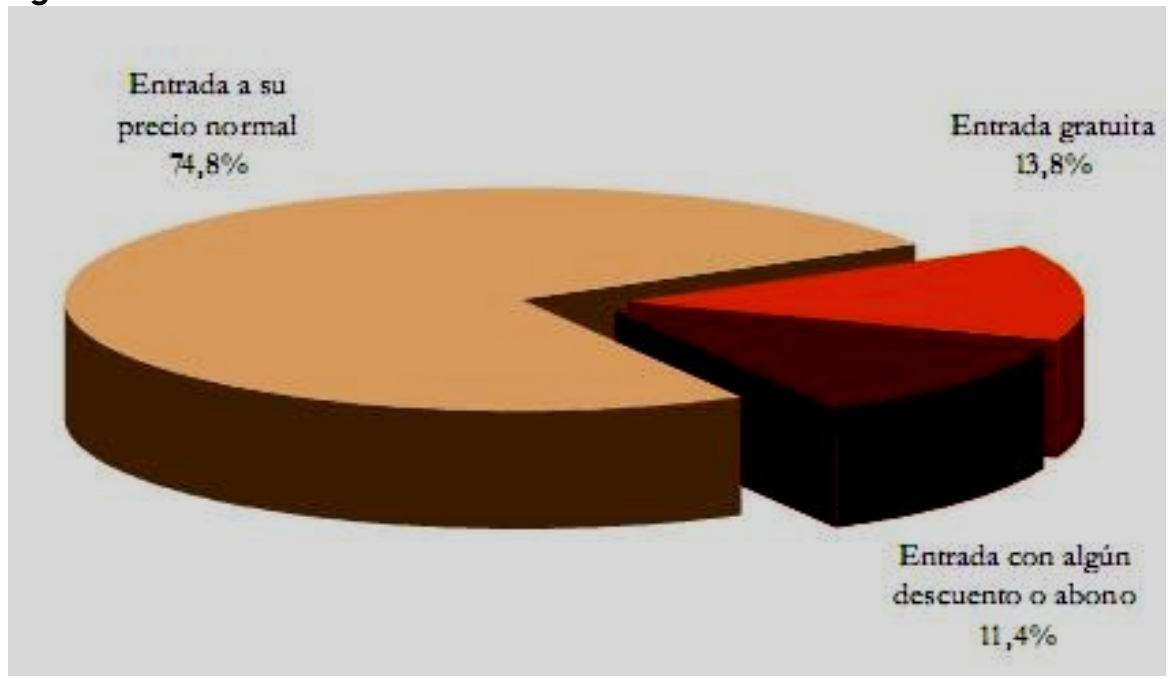

Fuente: Ministerio de Cultura

Resumen: Entrada a su precio normal $(74,8)$, Entrada gratuita $(13,8)$ y Entrada con algún descuento o abono $(11,4)$.

3.1.7 Personas que no van, o no van más veces al teatro en 2006-2007 según los motivos (En porcentaje de la población mayor de 15 años). 


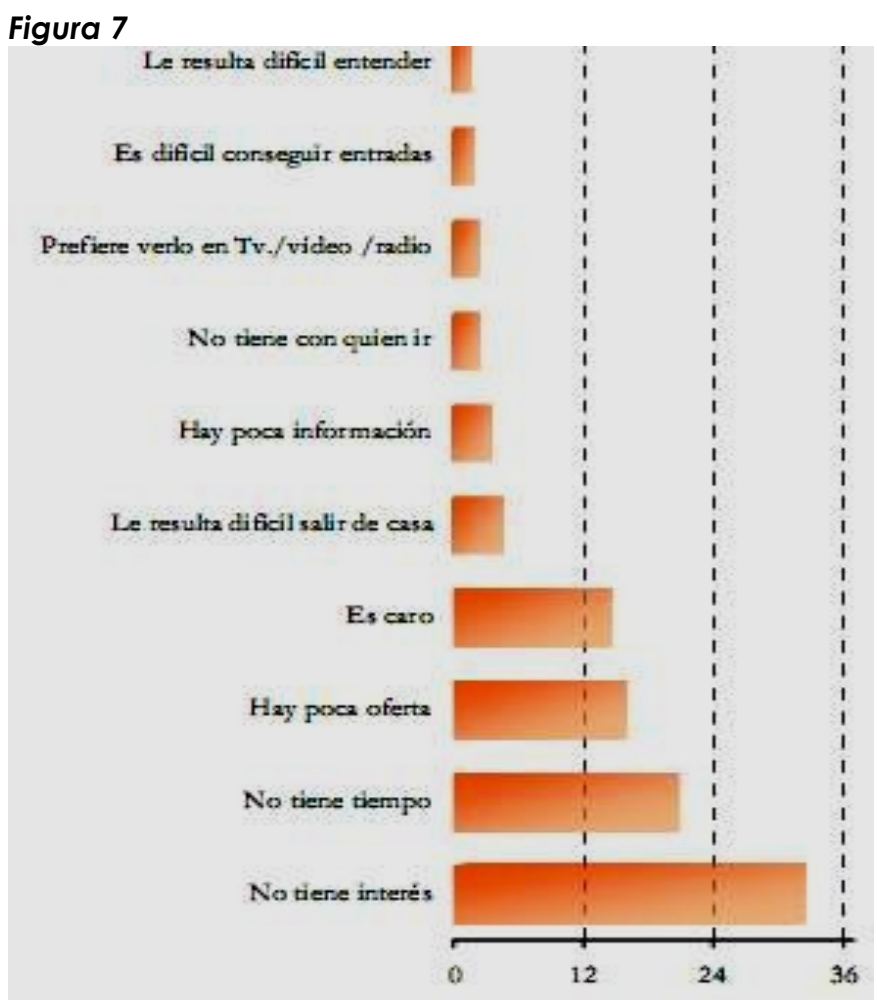

Fuente: Ministerio de Cultura

Resumen: No tiene interés (32,5), No tiene tiempo $(20,8)$, Hay poca oferta $(16,0)$, Es caro $(14,6)$, Le resulta difícil salir de casa $(4,6)$, Hay poca información $(3,5)$, No tiene con quien ir $(2,4)$, Prefiere verlo en TV/vídeo/radio $(2,2)$, Es difícil conseguir entradas $(1,8)$ y Le resulta difícil de entender $(1,6)$.

3.1.8 Personas que viven con menores de 15 años según la asistencia de estos menores al teatro en 2006-2007 y la opinión de estos menores respecto a esta actividad (En porcentaje de los que viven con menores de 15 años).

Figura 8

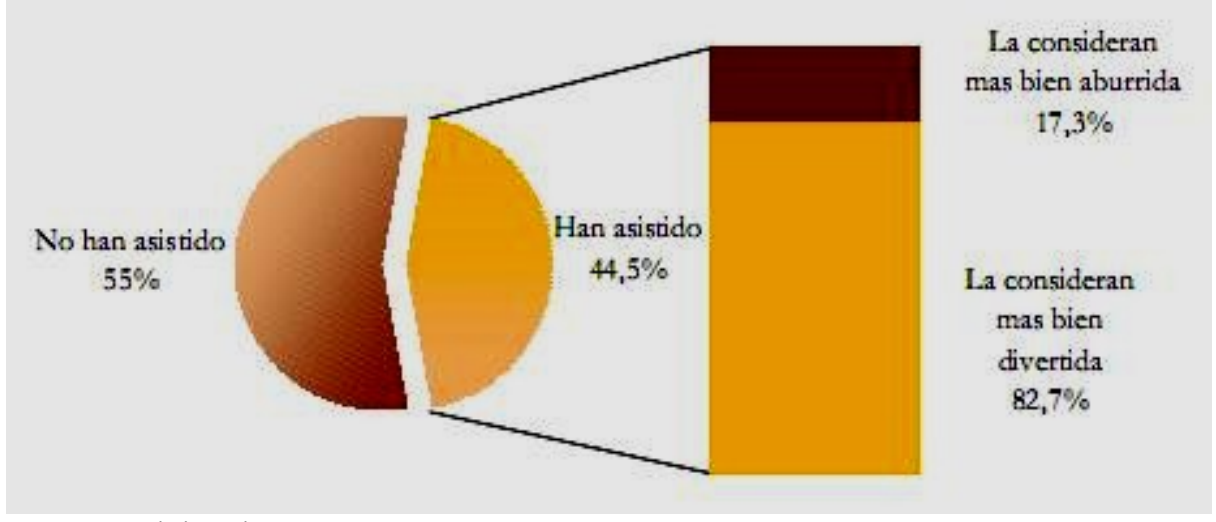

Fuente: Ministerio de Cultura

Resumen: Asistencia, han asistido $(44,5)$ y no han asistido $(55,5)$. Opinión de los que han asistido: Consideran la asistencia al teatro más bien divertida $(82,7)$ y consideran la asistencia al teatro más bien aburrida $(17,3)$. 
3.1.9 Personas que viven con menores de 15 años que han asistido al teatro en 2006-2007 según el tipo de acompañamiento (En porcentaje de los menores de 15 años que han asistido al teatro en el último año).

\section{Figura 9}

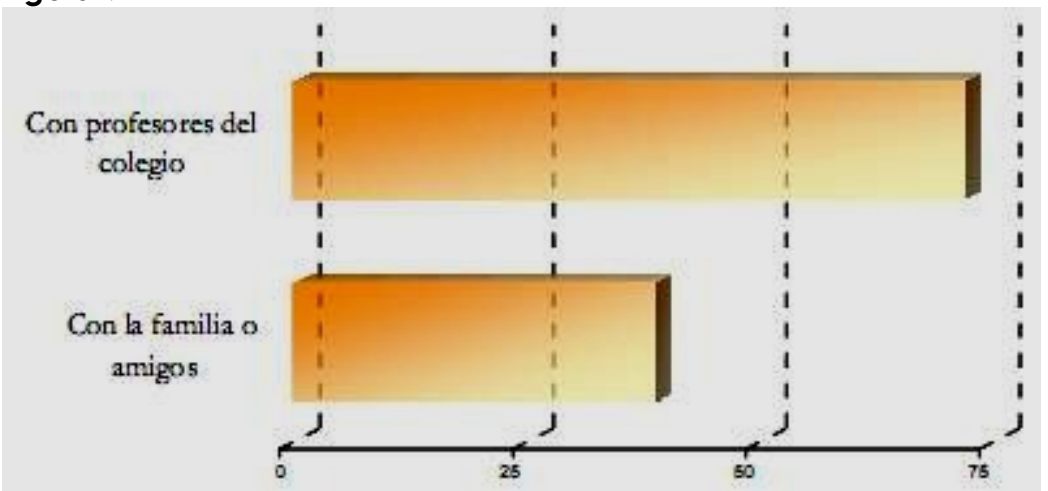

Fuente: Ministerio de Cultura

Resumen: Han asistido con profesores del colegio $(72,1)$ y han asistido con la familia 0 amigos $(28,9)$.

\section{Valoración de los datos aportados por las estadísticas culturales oficiales disponibles, realizadas por el Ministerio de Cultura}

El público declara preferir la música, los libros o el cine al teatro; incluso en su escala de prioridades culturales se coloca la visita a monumentos y museos por delante del teatro. Pero, aún así, el 19,1 \% de la población mayor de 15 años (unos 6.000 .000 de españoles) va al teatro al menos una vez al año. Y el $74,8 \%$ de los que fueron al teatro pagaron su entrada normal, sin descuentos.

Las encuestas hacen referencia a personas con estudios universitarios finalizados, o estudiantes entre 15 y 24 años.

También son destacables los resultados de la encuesta a menores de 15 años: el 44,5\% va al teatro al menos una vez al año, y el $82,7 \%$ de los que fueron, reconoce que se lo pasó bien. Cabe destacar que el $72,1 \%$ de los menores de edad fue al teatro con el colegio.

\section{Conclusiones:}

Como expresó el mismísimo Jacinto Benavente, cuando apenas tenía escrito una tercera parte de las obras teatrales que corporizaría a lo largo de su existencia -antes de recibir el Nobel de Literatura en 1922-, la percepción de un teatro en crisis, un teatro que se "muere", no es nueva, sino que se ha manifestado cíclicamente dependiendo de los contextos culturales. A cada uno de ellos el teatro ha respondido transformándose y adaptándose a las necesidades del público.

En la tesitura actual el teatro tiene una competencia multiforme. Cuando el progreso tecnológico nos ofrece Internet, cine, televisión, videojuegos..., parece que el teatro va a exhalar su última bocanada de aire. Pero la vinculación emocional de quien necesita vivir el directo proporciona oxígeno a un arte que aprende a diario cómo adaptarse a las nuevas posibilidades de un mundo digital. Hoy podemos disfrutar del teatro en nuestras casas, a través de Internet o adquiriendo entradas para representaciones desarrolladas variados formatos audiovisuales. Pero, por ejemplo, el teatro en las salas de cine -ya sea 
en directo o en diferido- nos permite seguir compartiendo un objeto de atención, interactuando con los que están sentados en las demás butacas. Incluso la ópera en directo ha hallado hueco en las pantallas de cine.

Internet presenta una serie de ventajas insoslayables en el consumo audiovisual. El profesor Tomás Frutos lo expresa claridad: "Tengamos en cuenta que Internet permite mirar las cosas con más sosiego, a cualquier hora, sin que el espacio ni el tiempo (ni siquiera un vendedor más o menos coercitivo) nos condicionen de manera notable."3

La imagen residual que transmitía el teatro en los últimos años sorprende cuando observamos los datos de las encuestas más recientes. 44 de cada 100 menores de 15 años ha ido al teatro el pasado año, la mayoría con el colegio, y de éstos, el $82 \%$ reconoce que disfrutó. Creemos que la educación en la percepción directa es fundamental para estimular culturalmente a las nuevas generaciones, sin abandonar el camino de las TT.II.CC. Los jóvenes han crecido utilizando televisión, ordenador y teléfono móvil como algo natural, pero es irrenunciable darles la oportunidad de disfrutar de un entretenimiento que se manifiesta más allá de una pantalla.

Convenimos con Joyanes en que: "Las redes de ordenadores enlazadas vía teléfono, satélite o fibra óptica, harán que la transmisión directa audio, texto y sonido (multimedia) sea tan revolucionaria como el ordenador, y cada vez más será una transmisión bidireccional e interactiva". ${ }^{4}$

Siempre hubo cierto interés en las programaciones escolares por incluir un primer contacto de los menores con las artes escénicas. Ahora el interés se convierte en un compromiso por devolver al individuo la posibilidad de participar colectivamente en actividades en directo.

La combinación del teatro con otros medios audiovisuales es la clave para su consolidación en la conciencia cultural colectiva de las nuevas generaciones. Por ejemplo, Eduardo Velasco, actor y director de la Compañía Avanti Teatro, siempre ha defendido que el apoyo de una plataforma televisiva multiplica la rentabilidad de una obra de teatro.

Según la SGAE, en 2007, se dio un pequeño incremento del 2,6\% en la asistencia a representaciones teatrales y coreográficas ${ }^{5}$ en relación al año anterior.

Daniel Martínez, presidente de Adetca (Associació d' Empreses de Teatre de Catalunya), afirma que la tónica general es un crecimiento lento pero sostenido, como demuestran las estadísticas de la temporada 2008-2009, que indican que la asistencia al teatro aumentó un $20 \%$ en público y un $37 \%$ en recaudación (403076 espectadores más, llegando a los 2654862 en total). Este aumento está vinculado al éxito de musicales ('Mamma mía' -con música del grupo sueco Abba-, 'Cabaret' -musical de Broadway convertido en película de amplio éxito más tarde-, 'Cómeme el coco negro' -music-hall tradicional- y tantos

3 TOMÁS FRUTOS, JUan. "Las organizaciones profesionales y las tecnologías de la información como nuevos valores del Periodismo" en Vivat Academia n 107 (2009). Consultada el 21-12-09. Disponible en http://www.ucm.es/info/vivataca/numeros/n107/articulo.htm\#lasorganiza

4 JOYANES AGUILAR, LUis. "Cambio Tecnológico y nueva sociedad de la Información: La Revolución silenciosa y la Cibersociedad" en Vivat Academia no 16 (2000). Consultada el 27-12-09. Disponible en http://www.ucm.es/info/vivataca/anteriores/dieciseis/cibermaneras.htm\#CAMBIO\%20TECNOL\%C3\%93GICO

5 La Vanguardia (Mayo 2008). Edición digital. Sección Cultura. Consultada el 27-12-10. Disponible en http://www.lavanguardia.es/lv24h/20080506/53460850024.html 
otros), pero, afortunadamente, este auge no ha supuesto perjuicio alguno al teatro clásico. También las salas alternativas han logrado aumentar su número de espectadores. ${ }^{6}$

La realidad del teatro no puede circunscribirse a las frías estadísticas, como afirman las profesoras Galán y Del Pino, puesto que "no todo es cuestión de porcentajes, la imagen que emanan y la capacidad del público para identificarse con los personajes de moda son los activos con los que cuentan anunciantes y agencias de publicidad a la hora de diseñar sus campañas"7. En este punto debemos entender que el teatro no es el vehículo predilecto de la publicidad y de ahí la necesidad de reinventarse día a día al margen de los circuitos publicitarios que sostienen financieramente otras manifestaciones culturales.

Nuestra investigación ha puesto de manifiesto que la cobertura de las representaciones teatrales sigue siendo una asignatura pendiente, más allá de lo anecdótico, para los medios de comunicación. No obstante, encontramos espacios valientes, sobre todo en la prensa, que continúan ofreciendo esta información, a los que debemos unir los amplios recursos de los que disponen las publicaciones especializadas e Internet -con páginas web reseñables como www.lateatral.com, www.todosalteatro.com 0 www.revistateatros.es

El panorama más desalentador lo encontramos en la televisión, con una situación sensiblemente peor que la de 2009. Han desaparecido estimulantes programas como La Mandrágora o Casa de América, destacados por su tratamiento del teatro. Se trata de oportunidades perdidas, que señalan un camino por el que hubiera merecido la pena haber continuado. Nuestra investigación, por desgracia, confirma la hipótesis inicialmente planteada. En los últimos años se ha dado una relación inversamente proporcional entre la asistencia a los teatros y la cobertura informativa específica sobre el teatro en las televisiones.

El futuro del teatro pasa por un mayor apoyo mediático que fomente su conocimiento y consumo. Un ejemplo: quizá la ópera sea el espectáculo más elitista de todas las artes escénicas, pero en Alemania los escolares asisten periódicamente a alguna representación. ¿̇Podría hacerse lo mismo con la zarzuela en España? Esa cultura de la asistencia a la sala puede ser reforzada por los medios de comunicación, quienes deben fomentar las artes escénicas en cualquiera de las manifestaciones.

El teatro es un lenguaje universal y polifacético. Retransmisiones (como los míticos Estudio1), galas, directos y temporadas de cualquier tipo de espectáculo sobre un escenario pueden hallar un hueco en las pantallas, diales y páginas de la prensa. El teatro debe aspirar a una normalización mediática, a una presencia acorde a su aceptación popular, para poder alejar para siempre el fantasma de una crisis más anímica que económica y cultural.

\author{
NIHIL ÓBSTAT. IMPRIMÁTUR
}

\footnotetext{
6 La Vanguardia (Diciembre 2009). Edición digital. Sección Cultura. Consultada el 27-12-10. Disponible en http://www.lavanguardia.es/lv24h/20080909/53535746784.html

7 GALÁN FAJARDO, Helena y DEL PINO ROMERO, Cristina. "Jóvenes, ficción televisiva y nuevas tecnologías", Área Abierta, $n^{\circ}$ 25. 2010. Pág. 13. Consultada el 15-03-2010. Disponible en http://revistas.ucm.es/inf/15788393/articulos/ARAB1010130003A.PDF
} 


\section{BIBLIOGRAFÍA}

CALDEVILLA DOMÍNGUEZ, David (2004). Campaña de imagen sobre el teatro en España. Vision Net. Madrid.

Cine\&Tele (20-11-09). Noticias Cine. Film Commissions, Instituciones. Sección Noticias. Consultada el 27-12-09. Disponible en http://www.cineytele.com/noticia.php?nid=28197

GALÁN FAJARDO, Helena y DEL PINO ROMERO, Cristina. "Jóvenes, ficción televisiva y nuevas tecnologías" en Área Abierta, n 25. 2010. Pág. 13. Consultada el 15-03-2010. Disponible en http://revistas.ucm.es/inf/15788393/articulos/ARAB1010130003A.PDF GROTOWSKI, Jerzy (2009). Hacia un Teatro Pobre. Siglo XXI.

JOYANES AGUILAR, Luis. "Cambio Tecnológico y nueva sociedad de la Información: La Revolución silenciosa y la Cibersociedad" en Revista Vivat Academia n 16 (2000). Consultada el 26-12-09. Disponible en http://www.ucm.es/info/vivataca/anteriores/dieciseis/cibermaneras.htm\#CAMBIO\%20T ECNOL\%C3\%93GICO

La Vanguardia (Diciembre 2009). Edición digital. Sección Cultura. Consultada el 27-1209. Disponible en http://www.lavanguardia.es/lv24h/20080909/53535746784.html

La Vanguardia (Mayo 2008). Edición digital. Sección Cultura. Consultada el 27-12-09. Disponible en http://www.lavanguardia.es/lv24h/20080506/53460850024.html MEYERHOLD, Vsevolod E. (2008). Textos Teóricos (serie Teoría y Práctica del Teatro) N 7 , $4^{a}$ Edición, Madrid.

MONZÓN, Cándido (1996). Opinión Pública, Comunicación y Política, Madrid: Tecnos. SÁNCHEZ MONTES, Maria José (2004). El Cuerpo Como Signo: La Transformación de la Textualidad en el Teatro Contemporáneo, Editorial Biblioteca Nueva, Madrid.

TOMÁS FRUTOS, Juan. "Las organizaciones profesionales y las tecnologías de la información como nuevos valores del Periodismo" en Revista Vivat Academia n 107 (2009). Consultada el 21-12-09. Disponible en http://www.ucm.es/info/vivataca/numeros/n107/articulo.htm\#lasorganiza Página Web oficial del Ministerio de Cultura. Gobierno de España. Consultada el 19-0611. Disponible en http://www.mcu.es/estadisticas/MC/CCE/Presentacion.html Página Web oficial del Ministerio de Cultura. Gobierno de España. Consultada el 19-0611. Disponible en http://www.mcu.es/estadisticas/index.html 